\title{
Entre fragmentos e narrativas: arquivos, mulheres e modernismo brasileiro
}

\section{Between Fragments and Narratives: Archives, Women, and Brazilian Modernism}

Texto recibido el 30 de octubre de 2017; devuelto para revisión el 30 de enero de 20I8; aceptado el 23 de octubre de 20I8, http://dx.doi.org/10.22201/iie.18703062e.2019.114.2678

Marina Mazze Cerchiaro Doutoranda em Estética e História da Arte pelo Museu de Arte Contemporânea da Universidade de São Paulo, Brasil, mmcerchiaro@gmail.com.

Lines of Research Art and gender; sculpture; modernism.

Líneas de investigación Arte y género; escultura; modernismo brasieño.

Publicaciones más relevantes "Construções do feminino nos anos 1930: a trajetória da escultora Adriana Janacópulos", Labrys. Estudos Feministas, v. 29 (2016), https://www.labrys.net.br/labrys29/arte/marina. htm; "Esculpindo a nação: diálogos entre história, arte e antropologia", La historia del arte en diálogo con otras disciplinas, Ix Jornadas de Historia del Arte (Santiago do Chile: Museo Histórico Nacional, 2016), 86-92, http://www.museohistoriconacional.cl/6r8/articles-72286_archivo_or.pdf; "Esculpindo o ideal de 'homem novo': discursos sobre raça, gênero e nação no Estado Novo", Politicas da Antropologia: Ética, diversidade e conflitos, Anais $3 \mathrm{O}^{\mathrm{a}}$ Reuniāo Brasileira de Antropologia (João Pessoa: Reuniāo Brasileira de Antropologia), http://www.abant.org.br/conteudo/ANAIS/3orba/admin/files/I4664748II_ARQUIVO_MarinaCerchiaroGTarteeantropologiazorba.pdf).

Roberta Paredes Valin Professora da Faculdade de Artes da Universidade Federal do Amazonas, Brasil, e mestre pelo Instituto de Estudos Brasileiros da Universidade de São Paulo, Brasil, robertaparedesvalin@gmail.com.

Lines of Research Personal archives; artists' notebooks; Brazilian modernism.

Líneas de investigación Archivos personales, cuadernos de artistas, modernismo brasileño.

Publicaciones más relevantes "Os cadernos de desenho de Anita Malfatti. Um diário de criação à revelia e índices de um projeto pictórico em Paris”, Revista do Instituto de Estudos Brasileiros, v. n. 63 (2016): 242-257, http://bibliotecadigital.fgv.br/ojs/index.php/reh/article/view/206o; "Cadernos-diários de Anita Malfatti — uma trajetória desenhada em Paris" (Diss. Instituto de Estudos Brasileiros da Universidade de São Paulo, 20I5), http://www.teses.usp.br/teses/disponiveis/3I/3II3I/tde-OIIO2OI5-I7425I/pt-br.php.

Morgana Souza Viana Mestranda pelo Programa de Culturas e Identidades Brasileiras no Instituto de Estudos Brasileiros da Universidade de São Paulo, Brasil, tugstom@gmail.com.

Lines of Research Sociology of art; art and gender.

Líneas de investigación Sociología del arte; arte y género. 
Publicaciones más relevantes "Anita Malfatti como retratista: análise das relaçôes entre a pintora e os retratados nos anos 1930-1940", Revista Epigrafe, v. 4, n. 4 (2017): 167-I84, https://www.revistas. usp.br/epigrafe/article/view/110923/132777.

Resumo Neste artigo, iremos apresentar os arquivos de duas historiadoras da arte brasileira: Marta Rossetti Batista e Aracy Amaral -salvaguardados pelo Instituto de Estudos Brasileiros-, como fontes para reflexão sobre a construção da memória das artistas Anita Malfatti, Tarsila do Amaral e da escultora Adriana Janacópulos. Buscaremos demonstrar que esses arquivos podem ser lidos como biografias das artistas e autobiografias das historiadoras, onde se percebem as imagens construídas das artistas e, ao mesmo tempo, fragmentos das imagens das historiadoras.

Palavras-chave Modernismo brasileiro; mulheres artistas; arquivos; biografias.

Abstract We discuss the archives of two Brazilian art historians: Marta Rossetti Batista and Aracy Amaral, held at the Institute of Brazilian Studies, as sources of reflection on the construction of the memory of Anita Malfatti, Tarsila do Amaral and Adriana Janacópulos. We demonstrate these archives can be read as biographies of artists and as autobiographies of historians, where the images these scholars constructed of the artists and fragments of images of these historians, can be perceived.

Keywords Brazilian modernism; women artists; archives; biographies.

Resumen Presentaremos los archivos de dos historiadoras de arte brasileńo: Marta Rossetti Batista y Aracy Amaral -salvaguardados por el Instituto de Estudios Brasileños-, como fuentes de reflexión sobre la construcción de la memoria de Anita Malfatti, Tarsila del Amaral y de Adriana Janacópulos. Demostramos que estos archivos pueden ser leídos como biografías de las artistas y como autobiografías de las historiadoras, en los cuales se perciben las imágenes construidas de las artistas y, al mismo tiempo, fragmentos de imágenes de las historiadoras.

Palabras clave Modernismo brasileño; mujeres artistas; archivos; biografías. 


\author{
MARINA MAZZE CERCHIARO/ROBERTA PAREDES \\ VALIN / MORGANA SOUZA VIANA \\ MUSEU DE ARTE CONTEMPORÂNEA DA UNIVERSIDAdE DE SÃO PAULO, BRASIL / \\ FACULDADE DE ARTES DA UNIVERSIDADE FEDERAL DO AMAZONAS, BRASIL / \\ INSTITUTO DE ESTUdOS BRASILEIROS DA UNIVERSIDADE DE SÃO PAULO, BRASIL
}

\title{
Entre fragmentos e narrativas: arquivos, mulheres e modernismo brasileiro
}

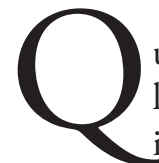

uando pensamos na primeira geração de artistas modernistas brasileiros, logo nos vêm à lembrança dois nomes de mulheres que foram incorporadas à narrativa canônica da história da arte brasileira: Anita Malfatti (I889-1964) e Tarsila do Amaral (I886-I973). Diversos historiadores, biógrafos e sociólogos ${ }^{1}$ dedicaram-se a estudar e compreender a trajetória e a produção dessas duas mulheres, mas até hoje os trabalhos sobre elas considerados referência são as monografias de fôlego Anita Malfatti, no Tempo e

I. Há alguns estudos fundamentais que revisam a produção e a trajetória das duas artistas, seja a partir de suas obras e dos documentos de seu arquivo pessoal, seja enveredando pelos muitos discursos que se projetaram sobre a vida e obra da artista e que foram responsáveis por definirem seu lugar na história durante muito tempo. No caso de Malfatti, ver: Tadeu Chiarelli, "Tropical, de Anita Malfatti”, em Um modernismo que veio depois (São Paulo: EDusP, 2008); Sônia Maria de Carvalho Pinto, "A controversa pintura de Anita Malfatti” (Diss. Universidade de São Paulo, 2007); Renata Cardoso, "Modernismo e Tradição: a produção de Anita Malfatti nos anos de 1920" (Diss. Universidade Estadual de Campinas, 20I2). Sobre Malfatti e Tarsila do Amaral, ver: Sérgio Miceli, Nacional Estrangeiro: história social e cultural do modernismo artístico em São Paulo (São Paulo: Companhia das Letras, 2003); Maria de Fátima Morethy Couto, "Caminhos e descaminhos do modernismo brasileiro: o confronto entre Anita e Tarsila", Esboços - Revista do Programa de Pós-Graduação em História da UFSC, Florianópolis, v. I5, n. 19 (março 2008): I25I50, https://doi.org/I0.5007/2175-7976.2008vi5ni9pi25; e Michele Greet, "'Exhilarating Exile’: Four Latin American Women Exhibit in Paris", Artelogie, n. 5 (2013). 
no Espaço, de Marta Rossetti Batista (1964-2007), ${ }^{2}$ e Tarsila: Sua Obra e Seu Tempo, de Aracy Amaral (1930), ${ }^{3}$ produzidas entre as décadas de 1960 e 1970.

Embora esses estudos não dialoguem com o pensamento feminista da história da arte, que começou a despontar nos estudos anglo-saxóes da década de 1970 (notadamente Por que não houve grandes mulheres artistas?, de Linda Nochlin), ${ }^{4}$ eles se mostraram inovadores no contexto intelectual brasileiro. A atuação de Marta Rossetti Batista e Aracy Amaral foi fundamental para que a história da arte modernista reconhecesse o protagonismo de Anita Malfatti e Tarsila do Amaral. A nosso ver, suas contribuiçóes para os estudos de arte e gênero residem justamente na opção das pesquisadoras pela reconstrução biográfica baseada em uma vasta e pioneira pesquisa em arquivos pessoais e públicos e em jornais de época.

A reconstrução biográfica faz parte de uma metodologia tradicional no campo da história da arte, cujo início pode ser atribuído aos textos de Giorgio Vasari (I550). 5 No caso de Marta Rossetti Batista e Aracy Amaral, ao lado da opção pela biografia, soma-se ainda o entendimento de que a história da arte baseia-se em uma evolução de estilos e escolas artísticas, que são fruto de um "espírito do tempo", evocando, assim, algumas noçóes presentes em Conceitos Fundamentais da História da Arte, de Heinrich Wölfflin, ${ }^{6}$ cujo impacto no Brasil foi imenso ao longo do século $\mathrm{xx}$. $^{7}$

No entanto, como lembra Eleni Varikas, ${ }^{8}$ a biografia foi também a primeira forma de escrita da história das mulheres, buscando provar que as mulheres eram tão capazes de fazer história quanto os homens:

2. Marta Rossetti Batista, Anita Malfatti no Tempo e no Espaço (São Paulo: Editora 34/ Edusp, 2006, $\mathrm{I}^{\mathrm{a}}$ ed. 1985).

3. Aracy Amaral, Tarsila, Sua Obra e Seu Tempo (São Paulo: Editora 34/ Edusp, 20Io, Iª ed. 1975).

4. Linda Nochlin, Art and Sexual Politics: Why There Have Been no Great Women Artists? (New York: Macmillan Publishing Co., 1973).

5. Giorgio Vasari, Les vies des meilleurs peintres, sculpteurs et architectes, vol. I (Paris: Berger-Levrault, 198I).

6. Heinrich Wölfflin, Conceitos Fundamentais da História da Arte (São Paulo: Martins Editora, 200I).

7. Sobre o impacto de Heinrich Wölfflin no Brasil, ver: Jens Baumgarten e André Tavares, "O Barroco colonizador: a produção historiográfico-artística no Brasil e suas principais orientações teóricas", Perspective, n. 2 (2013), http://perspective.revues.org/5538.

8. Eleni Varikas, "Lapproche biographique dans l'histoire des femmes", Les Cahiers $d u$ GRIE, $\mathrm{n}^{\circ}$ 37-38. Le genre de l'histoire (1988): 4I-56. 
L'usage de l'approche biographique dans l'écriture de l'histoire des femmes n'est pas une nouveauté. La biographie constitua la première forme d'histoire des femmes, depuis La Cité des Dames de Christine de Pisan aux première publications féminines et féministes du xIx ème siècle. D'abord parce que la démarche biographique fut pendant des siècles une composante centrale de la tradition historique - ce que l'on a tendance à oublier aujourd'hui. ${ }^{9}$

Para Varikas, o método biográfico incorpora as dimensóes da identificaçáo e da empatia, em seu potencial cognitivo, o que faz com que, no limite, toda biografia seja também uma autobiografia. Isso adquire significaçóes potentes quando biografado e biógrafo são mulheres, uma vez que representa a vontade de buscar uma autodefinição não nos estereótipos patriarcais, mas na experiência vivida por mulheres reais. Para a autora: "Le portrait de la femme étudiée devient souvent le miroir potentiel dans lequel la biographe chercherait à identifier son propre visage et ceux de ses semblables" . ${ }^{\text {IO }}$ Seguindo essa proposta, os arquivos de Marta Rossetti Batista e Aracy Amaral são fontes que permitem captar esses jogos de espelho, na medida em que revelam fragmentos das mulheres (pesquisadoras ou pesquisadas) emaranhados em narrativas de natureza biográfica.

Ao analisar detidamente as trajetórias de Tarsila do Amaral, Anita Malfatti e da escultora Adriana Janacópulos, Marta Rossetti Batista e Aracy Amaral rompem com o silêncio a que a história tradicionalmente submete as mulheres e as colocam como protagonistas. Para tanto, promovem a recuperação e construção de arquivos pessoais das artistas, a catalogação de suas obras, a escrita de biografias e a curadoria de exposiçóes. Nesse processo também traçam as próprias histórias tornando-se professoras, curadoras de acervos e moldando políticas institucionais. Ao preencher o espelho vazio que o cânone destina às mulheres artistas, as pesquisadoras constroem lugares para elas próprias como produtoras da memória e da história.

9. "O uso da abordagem biográfica na escrita da história das mulheres não é uma novidade. A biografia constituiu a primeira forma de história das mulheres, desde La Cité des Dames de Christine de Pizan até as primeiras publicaçóes femininas e feministas do século xix. Primeiramente porque o método biográfico foi durante séculos um componente central da tradição histórica —o que tendemos a esquecer hoje". (Tradução nossa, Varikas, "L'approche", 43).

Io. "O retrato da mulher estudada torna-se frequentemente o espelho potencial no qual a biógrafa procura identificar a própria face e a de suas semelhantes”. (Tradução nossa, Varikas, "L'approche," 52). 
Neste artigo, iremos apresentar os arquivos de Marta Rossetti Batista e Aracy Amaral, pertencentes ao Instituto de Estudos Brasileiros, ${ }^{\text {II }}$ como fontes que permitem compreender a construção da memória das artistas da primeira geração modernista brasileira - especificamente as pintoras Anita Malfatti, Tarsila do Amaral e a escultora Adriana Janacópulos- . Procuraremos demonstrar que esses arquivos podem ser lidos como biografias e autobiografias. Nossa intenção é compreendê-los como escrita do outro e de si mesmo; como jogos de espelhos que refletem tanto as imagens construídas das artistas, quanto fragmentos das imagens das próprias historiadoras. ${ }^{12}$

\section{Entre jogos de espelho: o arquivo, a biografia e a autobiografia}

No artigo Modernismo brasileiro: entre a consagração e a contestação, Ana Paula Cavalcanti Simionir ${ }^{13}$ afirma que o modernismo brasileiro se estabeleceu no

II. O Instituto de Estudos Brasileiros foi fundado em 1962 por Sérgio Buarque de Holanda com o propósito de ser um órgão de reflexão e crítica da sociedade brasileira, reunindo nesse objetivo diversas áreas e campos das humanidades. O arquivo, a Coleção de Artes Visuais e a biblioteca compóem o acervo do IEB, cujas atividades de pesquisa focam na preservaçáo e ampliação desses acervos culturais.

I2. Vários autores analisam os arquivos como autobiografias. Entre eles ver: Ana Paula Cavalcanti Simioni, "Memórias Insuspeitas de uma Artista Brasileira: Julieta de França e a escrita de si", em Julieta de França. Lembrança de Minha Carreira Artística, ed. Amanda Bonan, Lia Baron e Nara Reis (Rio de Janeiro: Coletiva Projetos Culturais/funarte, 20I4), II-I8; Priscila Fraiz, "A dimensão autobiográfica dos arquivos pessoais: o arquivo de Gustavo Capanema”, Revista Estudos Históricos, v. II, n. 2I (julho 1998): 59-88, http://bibliotecadigital. fgv.br/ojs/index.php/reh/article/view/206o e Michelle Perrot, "Práticas da Memória Feminina", Revista Brasileira de História, v. 9, n. I8 (agosto/setembro 1989): 9-18.

I3. Ana Paula Cavalcanti Simioni, "Modernismo brasileiro: entre a consagração e a contestação", Perspective, n. 2 (20I3): I-I4, http://perspective.revues.org/5539. Além de Simioni, diversos outros autores trazem novos olhares sobre o modernismo brasileiro buscando complexificar o debate demostrando os múltiplos modernismos em disputa na década de 1920 ; rever o papel dos artistas, dos críticos e dos historiadores nesse movimento; demonstrar as configuraçôes das coleçóes que compóen os acervos de museus brasileiros e seu diálogo com a arte moderna e os modernismos brasileiros, a fim de repensá-lo por meio das coleções; lançar luz nas relaçóes de poder e nas redes de sociabilidade que permitiram a determinados artistas lograrem êxito em suas carreiras; e revisar a oposiçáo acadêmico $\times$ moderno que contribuí para redimensionar a ideia de moderno e do próprio modernismo. Destacamos aqui os trabalhos de Tadeu Chiarelli, Um Jeca nos Vernissages: Monteiro Lobato e o desejo da criação de uma arte (São Paulo: EdusP, I995); Miceli, Nacional estrangeiro; e Ana Gonçalves Magalhães, 
final da década de I9Io e se consolidou ao longo de todo o século xx, consagrado por eventos artísticos de grande impacto insurgidos na capital paulista - como a exposição de Anita Malfatti em 1917 e a Semana de Arte Moderna de 1922 - , por um conjunto de agentes e práticas sociais legitimadoras subsequentes e pelos esforços de historiadores em escrever a história desse movimento por meio das declarações dos próprios participantes. Em sua análise, o modernismo "garantiu a certos grupos e a seus protagonistas um lugar de grande proeminência; eles tornaram-se, assim, símbolos culturais —e políticos- dos poderes de transformação oriundos das naçóes 'periféricas'". ${ }^{14}$

No que diz respeito às mulheres artistas, elas ganharam notoriedade na passagem do século xix para o xx. Se no Brasil dos oitocentos elas foram relegadas da história da arte à pecha de um conjunto de práticas excludentes e silenciadoras, que encontraram respaldo nos argumentos de incapacidade criativa e desigualdade entre os sexos, ${ }^{15}$ na virada do século seus trabalhos começaram a ser reconhecidos com os mesmos critérios concedidos aos artistas do sexo oposto. Algumas pintoras, em especial, conquistaram o direito à crítica profissional sem os estigmas femininos. ${ }^{16}$ Em ampla medida, foi com o modernismo que as artistas brasileiras passaram a ser levadas a "sério", ${ }^{17}$ alçando o posto de profissionais da arte, sobretudo a partir de I930. A crítica do final da década de I910 até 1940 , tanto de verve tradicionalista quanto moderna, e a historiografia do modernismo brasileiro, entre os anos de 1950 a I970, conferiram a essas artistas papéis determinados, marcas que, por muito tempo, moldaram suas trajetórias em função da glorificação de um discurso eloquente do movimento.

Nas décadas de 1960 e 1970, com o processo de revisionismo crítico do modernismo instaurado em território nacional, muitos pesquisadores se voltaram para as fontes primárias e secundárias —aos arquivos pessoais de artistas e intelectuais ligados ao período e aos de natureza pública - com o intuito de

\footnotetext{
"A narrativa de Arte Moderna no Brasil e as coleçóes Matarazzo", mac usp, Revista Museologia \& Interdisciplinaridade, v. I, n. I (20I2).

I4. Simioni, "Modernismo brasileiro", 5 .

15. Ana Paula Cavalcanti Simioni, "As mulheres artistas e os silêncios da história: a história da arte e suas exclusôes", Labrys, études féministes (janeiro/junho, 2007), http://www.labrys. net.br/labrysir/ecrivaines/anapaula.htm.

I6. Ana Paula Cavalcanti Simioni, Profissão Artista: pintoras e escultoras acadêmicas brasileiras (São Paulo: Editora da Universidade de São Paulo: Fapesp, 2008), 78.

17. "E os críticos levam as Mulheres 'a Sério': Revendo a Contenda Lobato versus Malfatti”, título de um dos subcapítulos do livro. Simioni, Profissão Artista, 78.
} 
rever as memórias do modernismo e (re)construir sua história refutando discursos unilaterais, desmistificando noçóes idealizadas, como as impostas às mulheres artistas, e, mais além, ampliando a construção de sentido sobre o período. Aracy Amaral ${ }^{18}$ e Marta Rossetti Batista ${ }^{19}$ desempenharam papel fundamental nesse processo. Além de escreverem monografias sobre Anita Malfatti e Tarsila do Amaral, documentaram suas obras, organizaram parte de seus arquivos e foram curadoras de várias exposiçóes dedicadas a elas. ${ }^{20}$ Seus estudos deixaram muitas indicaçóes e se mostram ainda hoje caminhos abertos para novas investigaçôes.

Em 2008, um ano após a morte da historiadora Marta Rossetti Batista, seu arquivo pessoal chega ao Instituto de Estudos Brasileiros doado por Luiz Ola-

I8. Aracy Amaral nasceu em 1930 e atuou como curadora, historiadora e crítica de arte. Professora titular da FAU-USP, foi diretora da Pinacoteca entre 1975 e 1979 , e do MAC-USP no período de 1982 a 1986. Jornalista graduada pela PUC São Paulo em 1959. Obteve pela Universidade de Sáo Paulo o título de mestra em filosofia e de doutora em artes. Nesse campo, produziu obras reconhecidas na história da arte brasileira como Tarsila, Sua Obra e Seu Tempo ([1975] 2010), Artes Plásticas na Semana de 22 ([1970] 1998) e Blaise Cendrars no Brasil e os Modernistas (1970). Como curadora trabalhou na $8^{a}$ Bienal do Mercosul e na Trienal do Chile. Em 1977 recebeu o prêmio John Simon Guggenheim e em 2006 o Fellowship, da Fundaçáo Bunge, pelas suas contribuiçóes na área de museologia. Seu acervo pessoal vem sendo gradativamente doado para o Arquivo IEB-usp desde 2016.

19. Marta Rossetti Batista nasceu em 1964. Formou-se em arquitetura pela FAU-USP e atuou como historiadora da arte e docente do IEB-UsP, dedicando-se ao estudo do modernismo brasileiro. Suas principais contribuiçóes são sobre a vida e a obra de Anita Malfatti com o livro Anita Malfatti no Tempo e no Espaço ([1985] 2006). Realizou também estudos sobre diversos momentos e atores do modernismo brasileiro como Mário de Andrade, Adriana Janacópulos, Cícero Dias, Tarsila do Amaral e Victor Brecheret. Com a obra Artistas Brasileiros na Escola de Paris - Anos 1920 ([1987] 20I2), ela condensou os seus estudos sobre os momentos iniciais do modernismo brasileiro e o seu contato com a produção europeia. Atuou ainda como curadora e também como diretora e docente do IEB-USP, consolidando o Arquivo IEb nos moldes que permitiram seu desenvolvimento.

20. Marta Rossetti Batista realizou, ao longo de sua vida como curadora, três importantes exposiçóes sobre Anita Malfatti: Anita Malfatti (I889-1964). Retrospectiva. São Paulo, MaC-USP e IEb-UsP, 1977 (melhor exposição do ano, APCA); Anita Malfatti, Centenário de Nascimento. I889/1989. São Paulo, MaC-usp e Ieb-usp, I989; e Anita Malfatti e Seu Tempo. Rio de Janeiro, ссвв, e São Paulo, мам, 1996. Em especial, as primeiras exposiçóes acompanharam a publicação da primeira versão do livro Anita Malfatti no Tempo e no Espaço, resultado de sua pesquisa biográfica sobre a artista. Aracy Amaral, por sua vez, conta com um currículo mais extenso de curadorias, entre elas as retrospectivas sobre Tarsila no MAC-RJ e no MAC-USP em 1969. Curiosamente, esse período coincide com a época em que realizava pesquisas para a obtenção do título de doutorado com a obra Tarsila-Sua Obra e Seu Tempo, em 1976. 
vo Batista, entáo viúvo da titular, e passou a integrar os três setores do instituto: arquivo, biblioteca e Coleção de Artes Visuais. O acervo é extenso e contém documentaçấo de natureza variada. A biblioteca reúne livros, catálogos, revistas e jornais sobre temas afinados com suas pesquisas, perfazendo um total aproximado de 2 mil volumes; e a Coleçáo de Artes Visuais abriga um conjunto com aproximadamente 180 peças de objetos populares. ${ }^{2 \mathrm{I}}$ Iniciamos o processamento dos documentos do arquivo entre os anos de 2013 e 20I4, por meio do projeto "De Anita ao IEb-Mapeamento e Descriçáo Parcial do Acervo Marta Rossetti Batista do IEв/USP", contemplado pelo Edital 20I2-20I3 do Programa de Pesquisa nos Acervos da usp, subsidiado pela Pró-Reitoria de Pesquisa da Universidade de São Paulo, sob a coordenação da professora Ana Paula Cavalcanti Simioni ${ }^{22}$ e supervisão de Elisabete Marin Ribas. ${ }^{23}$ As atividades de diagnóstico e catalogação do fundo permitiram entrar em contato com a vasta documentação e levantar diversas indagaçóes a respeito das relaçóes entre mulheres artistas, modernismo brasileiro, história da arte, arquivos e memória. ${ }^{24} \mathrm{O}$ vasto arquivo de Marta Rossetti Batista, composto de 247 caixas, abriga documentos referentes à sua variada atuação profissional como pesquisadora, professora, curadora e diretora do IEB-USP, sendo possível identificar a correspondência dos materiais a cada uma das funçôes exercidas pela historiadora. ${ }^{25}$

Já o arquivo de Aracy Amaral chegou ao IEB em 2016 doado pela própria pesquisadora. Foi processado em 2017 pela equipe do Arquivo IEB-USP, por meio do patrocínio do banco Itaú. Alguns documentos do arquivo foram

2I. Universidade de São Paulo, Instituto de Estudos de Brasileiros, Guia do IEB: o acervo do Instituto de Estudos Brasileiros, ed. Ana Lúcia Duarte Lanna (São Paulo: Instituto de Estudos Brasileiros, 20IO), 220.

22. Agradecemos à professora Ana Paula Simioni pela leitura atenta deste artigo e pelos seus comentários e sugestóes.

23. Agradecemos a Elisabete Ribas e a equipe do arquivo IEb a disponibilidade e o auxílio prestado em todo o processo de inventário e catalogação do Fundo Marta Rossetti Batista.

24. Além deste artigo, desenvolvemos algumas reflexóes sobre essas questóes em textos publicados em anais de congresso, ver: Marina Mazze Cerchiaro; Roberta Paredes Valin e Morgana Souza Viana, "O arquivo Marta Rossetti Batista: indícios de um fazer historiográfico", Anais VIII Jornadas de História da Arte: coleçôes, arquivos e narrativas, São Paulo (novembro 2015): IO-I3, http://www.humanas.unifesp.br/ppgha/publicacoes/livro-historia-da-arte-colecoes-arquivos-enarrativas/at_download/file; Marina Mazze Cerchiaro e Roberta Paredes Valin, "O arquivo Marta Rossetti Batista: mulheres, memória e história”, anais $O$ arquivo como espaço produtor de conhecimento, VIII Seminário Nacional do CMU - Memória e acervos documentais, Campinas, São Paulo (julho 2016): 26-28.

25. Conferir: Cerchiaro, Valin e Viana, "O arquivo", 537-548. 
expostos na exposição da Ocupação Aracy Amaral realizada no Itaú Cultural, em São Paulo, no mesmo ano. De modo geral, foi possível detectar que mais da metade de seu acervo está relacionada a tentativas de construir e unificar uma História da Arte Latino-Americana, por meio de projetos de pesquisa e de exposiçóes. Dado o recorte temático deste artigo, fizemos um levantamento de documentos referentes à Tarsila do Amaral que constituem apenas uma parcela do amplo e rico acervo de Aracy Amaral. As caixas com documentação sobre Tarsila do Amaral apresentam dados de pesquisa ao lado de propostas e/ ou organizaçóes de exposiçóes sobre a artista. Diferentemente do de Marta Rossetti Batista, as funçôes de pesquisadora e curadora são frequentemente entremeadas, sendo difícil notar com tanta clareza quais documentos pertencem a cada categoria. Tais diferenças refletem as metodologias empregadas pelas pesquisadoras ao longo de suas trajetórias que, também vale lembrar, estiveram em alguns momentos entrelaçadas.

Ambas tornaram-se pesquisadoras do modernismo brasileiro entre as décadas de 1960 e 1970, no mesmo momento em que se iniciou a valorização dos artistas modernistas, incitada pelos leilóes de arte na capital paulista. ${ }^{26} \mathrm{~A}$ Universidade de São Paulo, como espaço comum de formação, pesquisa e exercício da docência, permitiu que Marta Rossetti Batista e Aracy Amaral partilhassem entre si suas vidas profissionais. Dialogaram e trocaram experiências por inúmeras vezes em eventos científicos, defesas de mestrado e doutorado, publicaçôes e exposiçóes. Trabalharam juntas na catalogação da obra de Tarsila do Amaral, como narra com afeto Aracy Amaral:

Daí porque foi consensual e imediato o interesse pelo nome de Marta como uma das participantes do grupo de historiadoras a trabalhar na árdua catalogação da obra de Tarsila do Amaral. Sua capacidade de olhar, identificar, reconhecer, se apoiava em seus anos de pesquisas acompanhando o desenvolvimento de Anita Malfatti e seu tempo, que foi também a época de Tarsila. Ponderada e prudente, Marta Rossetti nesses longos meses de convívio mostrou-se uma companheira de trabalho atenta e com quem podíamos contar na apreciação e discussão de cada problema surgido. ${ }^{27}$

26. Aracy Amaral, "Aracy Amaral”, entrevista por SESc/sp, Revista E, n. 202, abril 8 (2014), http://www.sescsp.org.br/online/artigo/7445_ARACY+AMARAL\#/tagcloud=lista.

27. Aracy Amaral, "A contribuição de Marta Rossetti Batista", em Marta Rossetti - Escritos sobre arte e modernismo brasileiro, ed. Ana Paula de Camargo Lima (Sáo Paulo: Editora 34, 2012), 9 . 
Essas afinidades estáo relacionadas ao fato de as duas pesquisadoras terem procurado construir biografias das artistas baseadas, especialmente, em documentos pessoais. $\mathrm{O}$ acervo de Marta Rossetti Batista contém diversas cópias e alguns originais que provêm do arquivo de Anita Malfatti. ${ }^{28} \mathrm{O}$ mesmo acontece com o arquivo pessoal da escultora Adriana Janacópulos que, tendo em vista o desconhecimento do paradeiro da documentação da artista, acaba sendo a fonte mais importante de que dispomos hoje de informaçôes sobre ela. Já o de Aracy Amaral traz fotografias de Tarsila do Amaral e de suas obras, além de correspondências da artista —algumas delas para a própria historiadora—. Essa sobreposição de arquivos decorre do fato de Marta Rossetti Batista e Aracy Amaral terem convivido com as respectivas artistas.

No caso de Batista, seu primeiro contato com Anita Malfatti foi mediado por Flávio Mota, seu professor na Faculdade de Arquitetura da Universidade de Sáo Paulo na década de 1960. Batista integrava um projeto coordenado por Mota cujo objetivo era documentar as atividades e produçóes de artistas brasileiros vivos ou falecidos. ${ }^{29}$ Ela encontrou-se algumas vezes com a pintora, obtendo acesso à sua vasta documentação pessoal. Essa aproximação propiciou a construçáo de uma relação duradoura entre a historiadora e a artista, resultando em monografias, teses, inúmeros artigos, orientações de pesquisas, curadorias e entrevistas. Sua proximidade com a artista, mas sobretudo com sua família, foi fundamental para que esta doasse o acervo da artista ao IEB em 1989. O trabalho da historiadora com esse acervo foi extenso. Na tentativa de (re)construir a trajetória da artista, Batista reproduziu cartas, textos, manuscritos, fotografias e desenhos de Anita Malfatti. Ao percorrer a totalidade dos estilos artísticos e das fases da produção da pintora, assim como suas relaçóes sociais e profissionais, Batista abriu novas chaves de acesso para a vida e a obra de Anita, o que lhe permitiu construir uma imagem múltipla da artista que congrega as muitas "Anitas" que se mostraram possíveis no contexto do modernismo brasileiro: amiga, prima, irmã, pintora, desenhista, gravurista e educadora.

28. Durante o processo de extroversão do arquivo de Marta Rossetti Batista, deparamonos com dois documentos originais de Anita Malfatti que até aquele momento estavam desaparecidos de seu arquivo pessoal: Caminho do céu-estrada da saudade (carta escrita por Anita Mafatti relembrando os dez anos da morte do amigo Mário de Andrade) e A chegada da Arte Moderna no Brasil — versão final-. (Datiloscrito referente à conferência dada na Pinacoteca do Estado de São Paulo em I95I).

29. Batista, "Anita Malfatti", 9. 
Se Anita e Marta travaram contato por curto período de tempo, Tarsila e Aracy Amaral conviveram até a morte da pintora, pois pertenciam à mesma família. ${ }^{30}$ Tarsila, portanto, aparece no arquivo de Aracy não só como objeto de estudo, mas também como interlocutora, por meio de relaçóes de natureza pessoal e familiar com a pesquisadora. ${ }^{3 \mathrm{I}}$

Para além da dimensão pessoal, o desenvolvimento da carreira de Aracy Amaral como historiadora e curadora está intrinsecamente relacionado ao processo de valorizaçáo acadêmica e de mercado da produçáo de Tarsila, que, diferentemente da de Anita, inicia-se ainda em vida. Ao mesmo tempo que escreve e pesquisa a vida da pintora, Aracy organiza exposiçôes retrospectivas sobre ela nos museus de arte moderna e contemporânea do Rio de Janeiro e de Sáo Paulo (MAM-RJ e MAC-USP) em I969. A correspondência trocada com importantes diretores de museus e figuras do mundo da arte também corrobora essa associaçáo. $\mathrm{O}$ acervo apresenta um conjunto de cartas trocadas entre Aracy Amaral e as instituiçóes do MAM-RJ e MAC-USP, em que esta colabora com informaçóes sobre a vida de Tarsila do Amaral, auxiliando na identificação das obras, de seus títulos e das épocas nas quais foram realizadas. Aracy, assim, tem papel central na criação da imagem de Tarsila que é apresentada ao público nessas duas exposiçóes.

Assim como o arquivo de Marta Rossetti Batista, o de Aracy Amaral também procura recuperar documentos de diferentes fases da obra e da trajetória de Tarsila do Amaral, e não apenas referentes ao período canonizado pela historiografia modernista brasileira — a fase Pau-Brasil, época em que a pintora estava casada com o escritor vanguardista Oswald de Andrade. Isso permite ver uma Tarsila complexa, com uma produção ampla que se inicia na década de 1920 , prossegue até a década de 1970 e envolve experimentaçóes acadêmicas, modernas, de crítica social e de arte religiosa, embora a análise da produção posterior aos anos 1930 da pintora seja abordada apenas de modo marginal na biografia.

Ainda em relação às imagens das pintoras que podem ser depreendidas dos arquivos das pesquisadoras, as fotografias reproduzidas as colocam no seio familiar e expõem suas relaçóes de amizade mas, sobretudo, revelam suas origens sociais de modo marcante, nos levando a perceber diferenças fundamentais.

30. Aracy e Tarsila do Amaral eram primas.

3I. Exemplos dessa relação pessoal e familiar entre Aracy Amaral e a artista estão presentes no acervo da pesquisadora como denotam dois presentes que lhe foram dados por Tarsila: uma echarpe de Poirot e um livro em russo — lembrança do período em que a pintora esteve na União Soviética. 
Anita Malfatti provém de família de imigrantes italianos e alemães. Nascida em 2 de dezembro de 1889 em Sáo Paulo, residiu sempre na capital paulista, com exceção dos quase dez anos que passou no exterior a fim de aperfeiçoar seus estudos em arte e se profissionalizar. Muitas fotografias de seu arquivo pessoal reproduzidas no arquivo de Marta Rossetti Batista revelam sua vida em família, ladeada pelos irmãos, pais, avós, tios e amigas. ${ }^{32}$ Esses retratos, que têm a casa como pano de fundo, são recorrentes e podem ser vistos como elementos simbólicos não só de uma típica família tradicional e conservadora mas também de proteção e união, valores estimados pelos imigrantes em terras estrangeiras. As fotografias ainda registram as viagens de estudo na Alemanha (I9IO-I9I3), nos Estados Unidos (I9I4-I9I6) e na França (I923-I928), nas quais aparece entre amigas e familiares, com a cidade ao fundo, evocando a imagem de artista cosmopolita.

De modo antagônico a Anita, Tarsila do Amaral pertence a uma típica família da "aristocracia rural" paulista e gozou dos muitos privilégios dessa condição. Nascida em Capivari em I886, sua infância e juventude são bem documentadas nas fotografias existentes no arquivo de Aracy Amaral, mostrando-a na fazenda, em meio à família e aos amigos. O caráter aristocrático rural de sua vivência familiar é ressaltado nas fotos. Em uma delas de 1928, a pintora encontra-se no alto de uma escadaria, no canto direito, e seu pai, José Estanislau do Amaral Filho, ao pé da escada no centro da imagem. No canto esquerdo, uma serviçal negra, imóvel, quase como se fosse uma coluna a arrematar a lateral da construção. Nessa curiosa fotografia de família ficam evidentes as assimetrias de raça e gênero da elite rural paulista. Elas impactaram fortemente a identidade da pintora e sua produção e a levaram a iniciar sua formação artística tardiamente, aos 30 anos, quando já era mãe e divorciada. ${ }^{33}$

Os arquivos de Marta e Aracy trazem também estudos sobre os desenhos de Anita Malfatti e Tarsila do Amaral, que tinham como objetivo mapeá-los em amplo aspecto e, concomitantemente, consolidar suas imagens como desenhistas. No caso dos cadernos de desenhos de Malfatti, são inúmeras as cópias dos desenhos que aparecem ou como folhas avulsas ou coladas lado a lado (repro-

32. Batista "Anita Malfatti", 24-47.

33. Esta fotografia está publicada em Amaral, Tarsila, 341, e pode ser visualizada no link: https://books.google.com.br/books?id=io5c4Medh54C\&printsec=frontcover\&dq=tarsila+do+amaral+aracy+a maral\&hl=ptBR\&sa=X\&ved=oahUKEwi6wo3L6erQAhWC vZAKHU 3 ZA7oQ6AEIGzAA\#v=onepage \&q=Jos\%C3\%A9\%2oEstanislau\%2odo\%2o Amaral\%2odefronte\%20\%C3\%Ao\%2ocasa\%2oda\%2ofam\%C3\%ADlia\%2o\&f=false. 


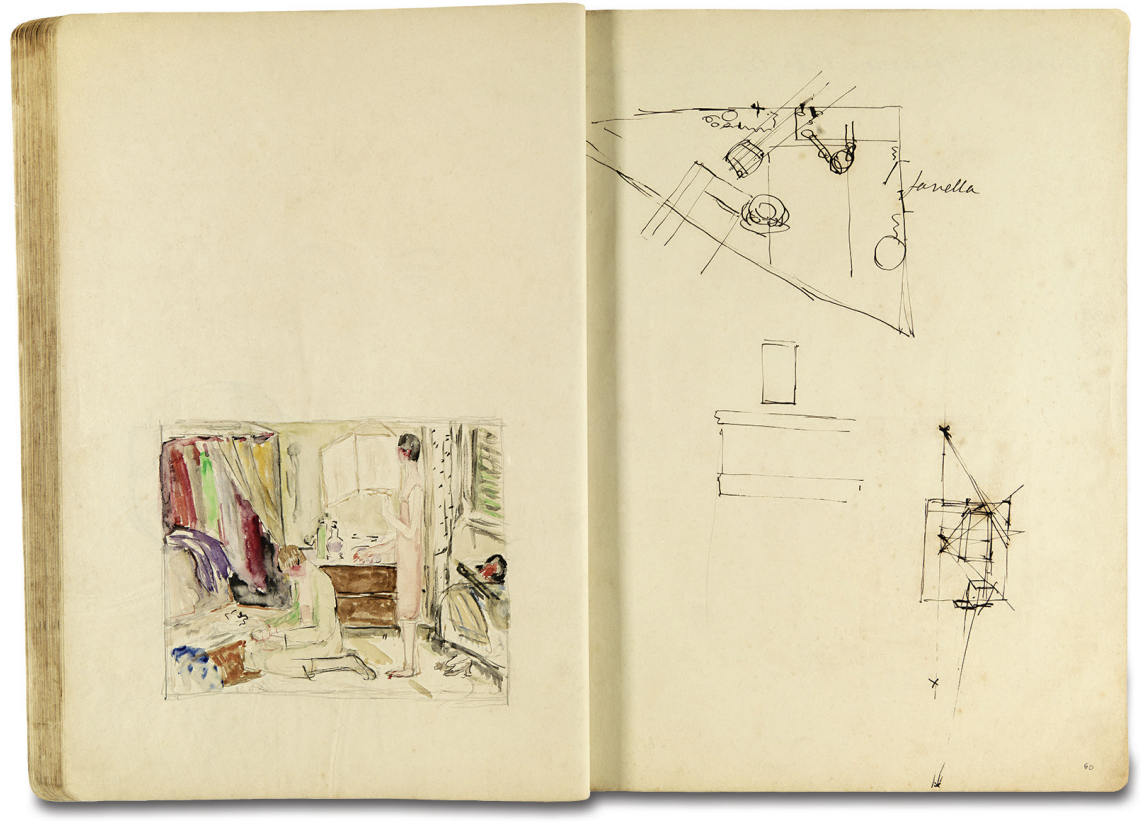

I. Anita Malfatti, Esboço para La rentrée, década de $1920,34.9 \mathrm{~cm} \times 24.9 \mathrm{~cm}$, Paris. Caderno de desenho. Carnet CAV-AM-CD-OOO4. Coleçáo de Artes Visuais, IEB/Usp.

duções pequenas) em suportes de papel rígidos de grande formato no arquivo de Batista, em uma espécie de mapeamento feito por imagens e anotaçóes. Essa prática táo evidente no arquivo da historiadora parece compor seu método de análise para os cadernos de Anita Malfatti e dos desenhos ali acolhidos, no intuito de criar uma linha de leitura que pudesse dar conta de organizar e fornecer informaçóes sobre datas, autoria, relações formais, estilísticas e temáticas, dentre outras, não evidentes em uma simples observação. Todo esse esforço analítico foi sintetizado por Marta na biografia da artista, tendo dedicado um espaço, ainda que pequeno, à Anita desenhista (Figs. I y 2). ${ }^{34}$

34. Batista "Anita Malfatti", 324-329. Sobre os cadernos de desenhos de Anita Malfatti, é fundamental destacar o texto de Ana Paula Cavalcanti Simioni e Ana Paula Felicíssimo Camargo de Lima para a Coleçáo Cadernos de Desenho no volume dedicado a Anita Malfatti, ver: Anita Malfatti, Cadernos de Desenho, ed. Lygia Eluf (Campinas: Editora da Unicamp, Imprensa Oficial do Estado de São Paulo, 20ıI) e também Roberta Paredes Valin,"Cadernos-diários de Anita Malfatti-uma trajetória desenhada em Paris” (Diss. Universidade de São Paulo, 2015). 


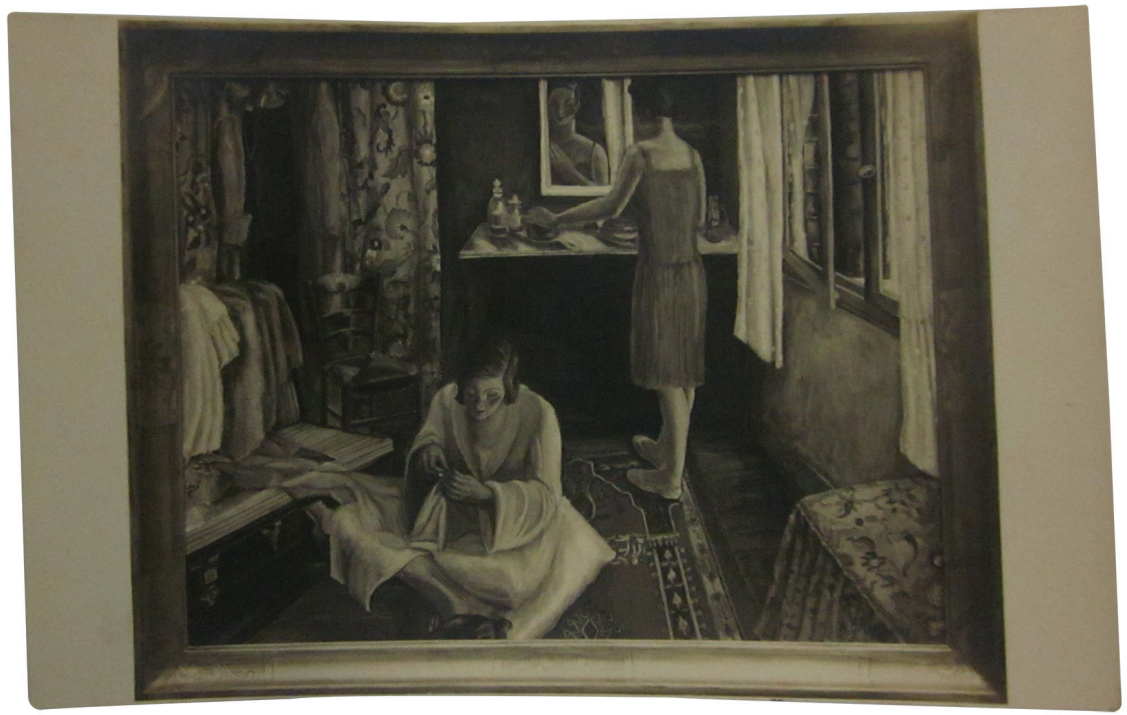

2. Fotografia da obra La rentrée pertencente ao Fundo Anita Malfatti (fam) do Arquivo do Instituto de Estudos Brasileiros da Universidade de São Paulo - IEB/UsP. Reprodução fotográfica de Christian Brandão.

As imagens de Anita Malfatti e Tarsila do Amaral que emergem dos arquivos das pesquisadoras são muitas e complexas. De um lado, trazem a dimensão da esfera privada, retratando a vida familiar e social; de outro, a carreira profissional que pode ser depreendida pelas fotografias de obras e recortes de jornais sobre elas.

Diferentemente das pintoras, Adriana Janacópulos não figura no cânone do modernismo brasileiro. Todavia, desenvolveu uma carreira de prestígio em sua época podendo ser considerada como um dos pioneiros da escultura modernista brasileira. Esquecida pela história, ela teve sua trajetória recuperada por Marta Rossetti Batista em um artigo publicado em 1989, a principal biografia sobre a artista. ${ }^{35}$ No arquivo da historiadora encontramos vários documentos relacionados à escultora. O período mais lacunar de sua trajetória diz respeito à sua infância, formação e início de carreira. Ele é transformado por Batista em narrativa biográfica com base em entrevistas com o filho da escultora, Pierre Wolko, e alguns poucos artigos de jornal. Nascida em I887, era filha do

35. Marta Rossetti Batista, "A escultora Adriana Janacópulos", Revista do Instituto de Estudos Brasileiros, n. 30 (1989). 
comerciante George Janacópulos e de Lucila Calógeras, sobrinha do historiador e político influente Pandiá Calógeras. Foi educada em Paris e, segundo os jornais da época, estudou escultura com Laporte-Blairzy (I865-1923), Raoul Larche (I860-I9I2) e Antoine Bourdelle (I86I-I929). Casou-se com o escultor russo Alexandre Wolkowyski — com quem teve dois filhos, Pierre e Josette-, vindo a se separar dele em I926. Entre 1922 a 1929 participou dos salóes de Outono, Tuileries e da Exposição de Arte Latino-Americana de 1924, chegando a expor pelo menos I5 obras, principalmente bustos. Após quase 20 anos na França, retornou ao Brasil em 1932.

Esse segundo período, sobretudo o ano de sua chegada ao país, pôde ser mais bem documentado por Marta Rossetti Batista, pois Pierre Wolko possuía um conjunto de fotografias e recortes de jornais pertencentes à escultora. Com a morte do último herdeiro da artista náo sabemos o paradeiro dessa documentação. No entanto, Batista reproduziu essas páginas que hoje integram o arquivo pessoal da historiadora, salvaguardado no Instituto de Estudos Brasileiros. Nelas, a memória construída diz respeito não à vida privada de Adriana Janacópulos, mas à sua carreira, com o intuito de demonstrar como sua produçáo foi intensa e reconhecida pela imprensa.

Em junho de 1932, Adriana Janacópulos realiza sua única exposição individual no Palace Hotel, no Rio de Janeiro, com o apoio da Associaçáo dos Artistas Brasileiros da qual era membro. O catálogo da mostra, fotocopiado por Batista, traz críticas de revistas francesas sobre a artista e o nome das obras expostas: 13 bustos, quase todos executados em Paris, e uma maquete intitulada Projeto de Pavilhão de Piscina, realizada por Adriana após sua chegada ao Brasil. As cópias das fotografias encontradas no arquivo denotam que a produção de Adriana Janacópulos era majoritariamente composta de bustos e pela escultura monumental, tendo executado os túmulos de Felippe de Oliveira (1933-1934) (fig. 3) e de Serafim Vallandro, no Rio de Janeiro; três monumentos públicos em homenagem aos estudantes mortos na Revolução Constitucionalista de 1932, encomendados pela Universidade de São Paulo para as faculdades de Direito, Medicina e Engenharia; Mulher, a obra mais emblemática de sua carreira, encomendada entre 1938 e 1942 por Gustavo Capanema para figurar no edifício-sede do Ministério da Educação e Saúde, no Rio de Janeiro; e o busto de sua irmã, Vera Janacópulos, instalado na Praça Paris, também no Rio de Janeiro (1957-1958). No entanto, poucas obras da escultora foram musealizadas, sendo que algumas delas se encontram conservadas no Museu Nacional de Belas Artes do Rio de Janeiro, graças à doação de seu filho (Fig. 3). 
3. Adriana Janacópulos, Vida exterior. Detalhe do túmulo de Felippe d'Oliveira no cemitério de São João Batista, Rio de Janerio. Fotografia reproduzida na revista Lanterna Verde. Fonte: Sociedade Fellipe d'Oliveira. Revista Lanterna Verde, Rio de Janeiro, v. 2 (I935).

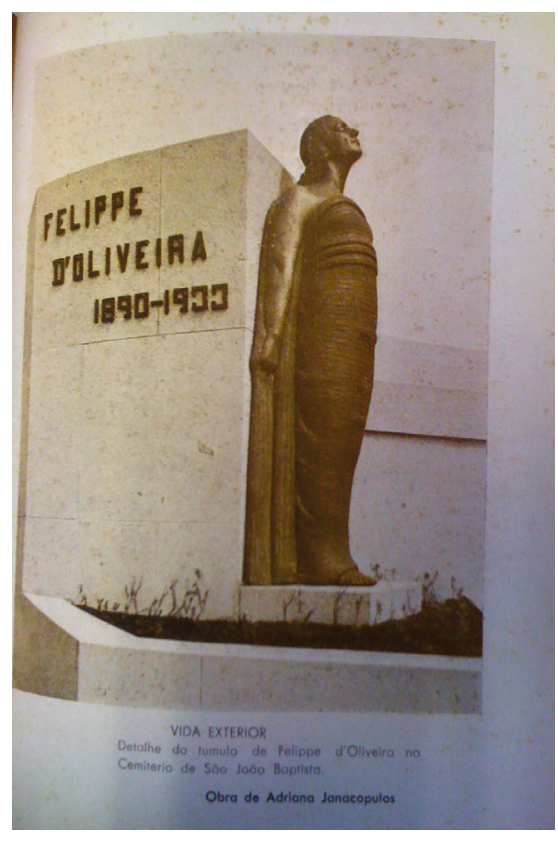

Se as imagens de Anita Malfatti e Tarsila do Amaral depreendidas dos arquivos evocam dimensốes da vida privada das artistas, o mesmo náo pode ser dito da de Adriana Janacópulos. Não há documentos pessoais sobre a escultora no arquivo de Marta Rossetti Batista. O único que nos remete levemente a esse caráter é a fotocópia de uma fotografia de um esboço de um Cristo Redentor, na qual se lê no verso: "Priere montrer a Vera. Photographie du dessin que j’ai envoyé au Chili. Le dessin avant $60 \times 90$. Pourvue que j’ai la commande. Maman". ${ }^{36}$ Esse documento também revela o quanto a historiadora procurou reproduzir fielmente o arquivo da artista (Fig. 4).

A imagem de Adriana Janacópulos construída pelo arquivo é definitivamente pública, sendo a principal fonte documental, sem dúvida, os recortes de jornais brasileiros sobre a artista. ${ }^{37}$ Neles, a escultora é apresentada como profissional dedicada e talentosa, cuja obra dialogava com a vertente figurati-

36. Por favor mostrar a Vera. Fotografia do desenho que enviei ao Chile. O desenho tem $60 \times 90$. Que eu obtenha a encomenda. Mamãe.

37. Desenvolvemos aqui questôes já esboçadas em artigo anterior. Cerchiaro e Valin "O arquivo". 

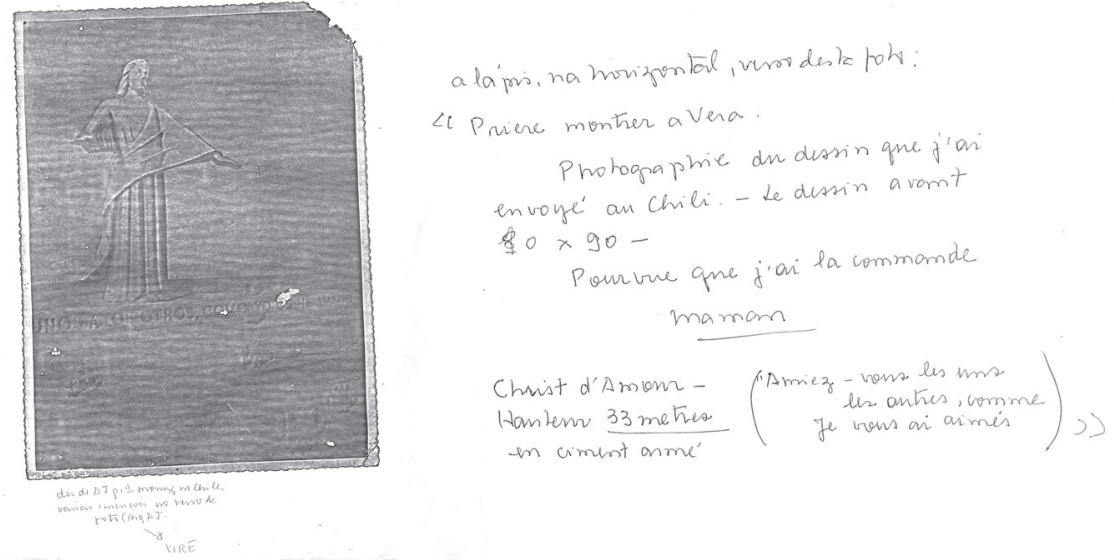

4. Fotocópia (frente e verso) realizada por Marta Rossetti Batista de uma fotografia do desenho de Adriana Janacópulos do Cristo Redentor. Junto a imagem do desenho vê-se uma anotação a caneta feita pela historiadora "des. de A. J. p/ monumento Chile. Várias mençóes no verso da foto (arq. A. J.) Vire.” No verso da cópia lê-se: "a lápis na horizontal, verso desta foto "Priere montrer a Vera Photographie du dessin que j’ai envoyé au Chili -- Le dessin avant $60 \times 90$-- Pourvue que j'ai la commande. Maman. Christ d'Amour - Hautesse 33 metres em ciment armé. 'Aimezvous les uns les autres, comme je vous ai aimés. " Arquivo do IEB - USP, Fundo Marta Rossetti Batista, código de referência: MRB-AJ-I38.

va do "modernismo classicizante" difundido na França na década de 1920 por artistas como Antoine Bourdelle, Charles Despiau e Aristide Maillol. ${ }^{8}$ Embora, na maioria dos artigos, a obra e a carreira de Adriana Janacópulos não fossem julgadas com base em uma suposta feminilidade inerente, sua "condição feminina" aparece enfaticamente quando os articulistas se referem a sua identidade de artista. Estereótipos da mulher elegante, da mãe dedicada, da dona de casa zelosa e da profissional humilde são frequentemente acionados. ${ }^{39}$

Contradições estas que, de diferentes formas, estâo presentes nas imagens das três artistas reveladas pelos arquivos de Marta Rossetti Batista e Aracy Amaral. Elas sinalizam que ser mulher artista no Brasil dos anos de 1920 e 1930

38. Como a própria artista afirma em entrevistas, ela buscava a simplificação e a harmonia das formas, a ausência de ornamentos, o respeito ao bloco e a valorização do estático.

39. Marina Mazze Cerchiaro, "Construçóes do feminino nos anos 1930: a trajetória da escultora Adriana Janacópulos”, Labrys, études féministes (janeiro/ junho, 20I6), http://www. labrys.net.br/labrys29/arte/marina.htm (acesso em 6/12/2016). 
envolvia não só ser reconhecida como profissional, mas também ter sua persona construída por determinados estereótipos de gênero que vão da mulher frustrada e assexuada à musa, da artista humilde à mãe dedicada. ${ }^{40}$ Essas ambivalências perpassam a própria identidade das artistas. No caso de Tarsila do Amaral, pode-se perceber as contradiçóes em equacionar sua origem, assentada na aristocracia rural paulista, com a experiência cosmopolita vivenciada em Paris, tão necessária para que pudesse obter reconhecimento como artista modernista. Já Anita Malfatti e Adriana Janacópulos assumem a árdua tarefa de tentar conciliar experiências progressivas vividas na Europa e nos Estados Unidos das décadas de 1910 e $1920,{ }^{41}$ com o ambiente artístico ainda incipiente e com discursos provincianos, conservadores e normatizadores a respeito do que era "ser mulher". Em termos plásticos, a opção por vertentes estéticas entre a modernidade e a tradição aparece como solução para esses dilemas.

Em seus arquivos, Aracy Amaral e Marta Rosetti Batista constroem biografias das artistas que diferem daquelas que emergem de suas monografias por serem narrativas fragmentárias e polifônicas, baseadas em materiais diversos. Revisitar a trajetória dessas artistas por meio das diversas vozes registradas nos arquivos (das pesquisadoras, das próprias artistas e de suas famílias, dos jornais e de documentos institucionais) permite não só repensar a participação das mulheres na primeira geração de modernistas brasileiros mas, também, captar as relaçóes de afeto e proximidade que as pesquisadoras tinham com as mulheres que estudavam. is

40. Sobre a construção da feminilidade nas décadas de 1920 e 1930 no Brasil, ver: Natasha Ostos, "A questáo feminina: importância estratégica das mulheres para a regulação da população brasileira (1930-1945)", Cadernos Pagu, Campinas, n. 39 (dezembro 20I2), http://dx.doi. org/IO.1590/Soro4-833320120002000II; Maria Inez Machado Borges Pinto, "Cultura de massas e representaçôes femininas na paulicéia dos anos 20", Revista brasileira de História, São Paulo, v. I9, n. 38 (1999), http://dx.doi.org/I0.1590/SoI02-oI881999000200007; Silvana Vildore Goelnner, Bela, maternal e feminina. Imagens da mulher na Revista Educação Physica (Injuí: Unijuí, 2003); Susan K. Besse, Modernizando a desigualdade: reestruturação da ideologia de gênero no Brasil, I9I4-I940 (São Paulo: UNESP, I999). Especificamente sobre as construçôes de gênero acionadas pela crítica ao tratar de Anita Malfati, Tarsila do Amaral e Adriana Janácopulos, ver: Couto, "Caminhos", 2008, e Cerchiaro, "Construçôes”, 2016.

4I. Ana Paula Cavalcanti Simioni, "Diásporas do moderno. Artistas brasileiros em Paris, década de 1920", em Arte e Vida Social. Pesquisas recentes no Brasil e na França, ed. Alain Quemin e Glaucia Villas Boas (Marselha: Open Edition, 2016). 